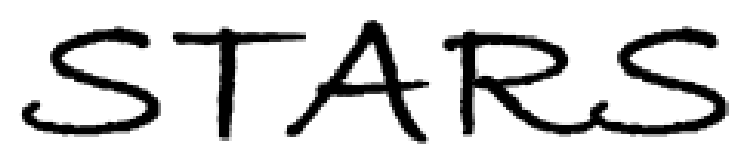

University of Central Florida

STARS

$1-1-2007$

\title{
Logistics and staging areas in managing disasters and emergencies
}

\author{
Naim Kapucu \\ University of Central Florida \\ Wendell C. Lawther \\ University of Central Florida \\ Sommer Pattison \\ University of Central Florida
}

Find similar works at: https://stars.library.ucf.edu/facultybib2000 University of Central Florida Libraries http://library.ucf.edu

This Article is brought to you for free and open access by the Faculty Bibliography at STARS. It has been accepted for inclusion in Faculty Bibliography 2000s by an authorized administrator of STARS. For more information, please contactSTARS@ucf.edu.

\section{Recommended Citation}

Kapucu, Naim; Lawther, Wendell C.; and Pattison, Sommer, "Logistics and staging areas in managing disasters and emergencies" (2007). Faculty Bibliography 2000 s. 7284.

https://stars.library.ucf.edu/facultybib2000/7284

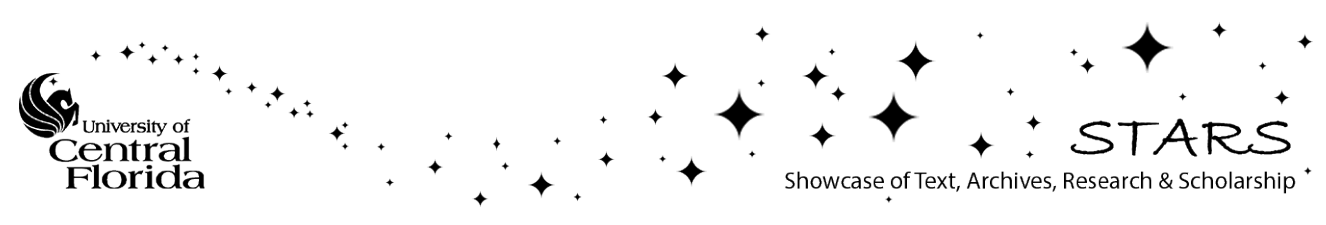




\section{Journal of Homeland Security and Emergency Management}

Volume 4, Issue 2 2007

Article 3

\section{Logistics and Staging Areas in Managing Disasters and Emergencies}

Naim Kapucu, University of Central Florida Wendell C. Lawther, University of Central Florida Sommer Pattison, University of Central Florida 


\title{
Logistics and Staging Areas in Managing Disasters and Emergencies
}

\author{
Naim Kapucu, Wendell C. Lawther, and Sommer Pattison
}

\begin{abstract}
Emergency management is often evaluated and improved after the occurrence of a disaster, especially in the case of preparedness. This paper discusses the importance of logistics planning and operation as it relates to disaster preparedness. The selection of field logistics sites such as staging areas, prior to the occurrence of a natural or man-made disaster, is a crucial step in emergency planning and management. Selection can be aided and kept consistent by preidentifying state and county-level guidelines for staging areas. This paper reviews state and county criteria for the pre-selection of staging areas and discusses supporting logistical operations in disaster management.
\end{abstract}

KEYWORDS: disaster management, logistics, staging areas, points of distribution, emergency planning

Author Notes: We are grateful for the sponsorship of Central Florida Fairgrounds, Center for Community Partnerships and the College of Health and Public Affairs at the University of Central Florida. We are also grateful to county, state, and federal emergency management officials as well as several representatives from city and county emergency management agencies. 


\section{INTRODUCTION}

Emergency management is a continual process of development in which logistics planning is often evaluated and improved after a disaster. In 1992, the State of Florida suffered from 40 civilian deaths, 30 billion dollars in property damage, 82 thousand damaged or destroyed businesses, and over 250 thousand new homeless as a result of Hurricane Andrew. Following the destruction, the State of Florida began to reexamine existing levels of preparedness and response. Less than two weeks after the hurricane hit the state, Governor Lawton Chiles issued Executive Order 92-242 establishing the Governor's Disaster Planning and Response Review Committee (Mittler 1997). The purpose of the committee was to evaluate state and local response plans and operations for natural and man-made disasters and make recommendations for improvement. Among the resulting recommendations were improved inter-agency coordination and communication, increased emergency management funding, advanced emergency management training, and well-constructed plans for response and recovery by each level of government (Mittler 1997).

\section{Table 1: Costliest hurricanes to hit Florida}

\begin{tabular}{|l|l|l|l|l|}
\hline Rank & Hurricane & Year & Category & Damage \\
\hline 1 & Andrew (SE FL, SE LA) & 1992 & 5 & $26,500,000,000$ \\
\hline 2 & Charley (SW FL) & 2004 & 4 & $15,000,000,000$ \\
\hline 3 & Ivan (AL/NW FL) & 2004 & 3 & $14,200,000,000$ \\
\hline 4 & Frances (FL) & 2004 & 2 & $8,900,000,000$ \\
\hline 6 & Jeanne (FL) & 2004 & 3 & $6,900,000,000$ \\
\hline 11 & Opal (NW FL, AL) & 1995 & 3 & $3,000,000,000$ \\
\hline 13 & Agnes (FL, NE U.S.) & 1972 & 1 & $2,100,000,000$ \\
\hline 18 & Betsy (SE FL, SE LA) & 1965 & 3 & $1,420,500,000$ \\
\hline 19 & Elena (MS, AL, NW FL) & 1985 & 3 & $1,250,000,000$ \\
\hline 25 & Erin (NW FL) & 1995 & 2 & $700,000,000$ \\
\hline
\end{tabular}

Source: NOAA/NWS, www.nhc.noaa.gov, 2006

Twelve years later, it became evident that more improvements were still needed. In 2004, four major hurricanes - Charley, Frances, Ivan and Jeanne provided the state with further knowledge of the weaknesses that still existed in emergency management plans and operations. The 2005 Hurricane Season further identified existing weaknesses on a national scale. Table 1 above illustrates the disastrous fiscal damage that hurricanes have had on the State of Florida. The ordering is made based on the size of the damage caused by each hurricane. 
Emergency management operations in the State of Florida include the Florida Department of Emergency Management (FDEM), county and city emergency management divisions, mutual aid agreements, County Emergency Management Plans (CEMPs), coordinated logistics planning, and comprehensive emergency management training. FDEM requires that county departments of emergency management develop county logistics plans as part of their CEMPS. To help guide county planning, FDEM has identified a list of specific, minimum requirements for County Staging Areas (CSAs). The intended result is a county logistics plan that serves to strengthen preparedness efforts at the county-level by providing detailed, strategic procedures for disaster management. CEMPs should also define county roles and responsibilities for logistical operations including the pre-identification of CSAs and Points of Distribution (PODs).

At the federal level, developments such as the National Response Plan (NRP) and Federal Emergency Management Agency (FEMA) grant programs continue to bolster state efforts. County, state and federal departments seek to further identify the weaknesses that exist within emergency management including disaster planning, recovery, and response.

An important element affecting emergency management planning and operations at all levels of government is logistics, particularly the field logistics site or staging area. A staging area is a site selected by the appropriate federal, state, and county or city government for the purposes of pre-positioning and disbursement of disaster relief equipment and supplies. This paper will discuss the pre-selection of staging areas as a decisively crucial step in emergency logistics planning. Specifically, this study seeks to achieve the following goals: suggest revisions of current practices of logistics planning and operations; determine the purpose of staging areas and define the types of staging areas utilized; distinguish staging areas from other field logistics sites; and identify the criteria used for the selection of staging areas by FEMA, FDEM, and county/city emergency management departments.

NRP designates FEMA as the responsible agency for coordinating logistics during disaster response operations (DHS 2004). In response to Hurricane Katrina, the highly bureaucratic supply processes of FEMA were not sufficiently flexible and efficient and failed to leverage the private sector and $21^{\text {st }}$ Century advances in supply chain management. Even when an agency came directly to FEMA with a list of available resources that would be useful during the response there was no effective mechanism for efficiently integrating and deploying these resources. Nor was there an easy way to find out whether an alternative source, such as those found in the private or nonprofit sectors, might have been better to fill the need.

The Department of Homeland Security, in coordination with state and local governments and in cooperation with the private sector, should develop a 
modern, flexible, and transparent logistics system. This system should be based on established contracts for stockpiling commodities at the local level for emergencies and the provision of goods and services during emergencies. The Federal government must develop the capacity to conduct large-scale logistical operations that supplement and, if necessary, replace state and local logistical systems by leveraging resources within both the public sector and the private sector (Townsend 2006).

\section{BACKGROUND INFORMATION}

Disaster logistics can be defined as "the capability to identify, dispatch, mobilize, and demobilize, and to accurately track and record available critical resources throughout all incident management phases" (GAO 2006: 47). Disaster logistics include elements such as the staging effort, accountability, the rehabilitation section, and the resources unit. Those working as part of the staging effort oversee the initial arrivals of unassigned units of materials and supplies. Accountability maintains the tracking of resources and the safety of individuals. The rehabilitation section manages the monitoring of deployed personnel whereas the resource unit oversees all equipment (Lindell, Prater, and Perry 2007).

Finding ways to get supplies to those persons in need during disasters requires flexibility and creativity since the dynamic environment of disasters can be expected to produce highly unpredictable logistical needs. This necessitates constant communication among disaster response agencies in order to deliver supplies in a timely manner to those areas critically affected (Levans 2005; Sule 2001; Gooley 1999). Networks of government agencies at varying levels as well as private sector entities can be effective in the coordination of logistical response to disasters. In fact, private sector practices may be applied to increase logistical performance in managing and responding to disasters (Wassenhove 2006). ${ }^{1}$

Throughout various articles, scholars have increasingly referred to the topic of emergency and disaster management providing insight on dealing with such catastrophic events as the 9/11 terrorist attacks and recent hurricanes. Towards which they have identified four primary steps of emergency management: mitigation, preparedness, response, and recovery (Kapucu and Van Wart 2006; McEntire 2004; Comfort 2002; Waugh 2000; Auf der Heide 1989). Of these steps, response and recovery have been the dominant focus of emergency management research (Perry and Lindell 2007; Waugh 2000, 2006; Drabek 2003; Dynes and Tierney 1994).

Preparedness also has received significant attention from emergency management scholars. For example, McEntire and Myers (2004) discuss the

\footnotetext{
${ }^{1}$ Secretary Chertoff also acknowledges this fact after the failed logistics planning and response to Hurricane Katrina (Chertoff 2005; Keane 2005).
} 
process of preparedness that should be undertaken by governments listing the following steps as vital to emergency management: "establishing emergency management ordinances; assessing hazards, vulnerability and risks; creating an emergency operations plan; developing a warning system; identifying and requiring resources and grants; instituting mutual aid agreements; training; and exercising and educating the public" (140). Logistics and staging area selection can be considered as part of disaster preparedness. However, we found that logistics and staging area selection have not been addressed in the literature. Having an operable logistics and staging area selection plan in place prior to the occurrence of a man-made or natural disaster is essential to preparedness and should be in effect at all levels of government - national, state, and local.

On the national level, the National Incident Management System (NIMS) acknowledges preparedness as a similar process that "focuses on guidelines, protocols, and standards for planning" (Center for Community Partnerships 2006). Logistical planning and operations are key elements that should be identified in these guidelines. Although NIMS does not specifically address site selection criteria, it does recognize the importance of pre-selection as part of the planning process and the need for a pre-selected site during response mobilization as it states "the mobilization process may include equipping, training, and/or inoculating personnel; designating assembly points that have facilities suitable for logistical support; and obtaining transportation to deliver resources to the incident most quickly, in line with priorities and budgets" (FEMA NIMS B, 62004).

The diagram found below illustrates the outward flow of resources from each assembly point beginning at the federal staging area onto the state staging area(s) where from resources are then disseminated through various distribution points to the general public in need. 
Figure 1: Resource Staging and Distribution

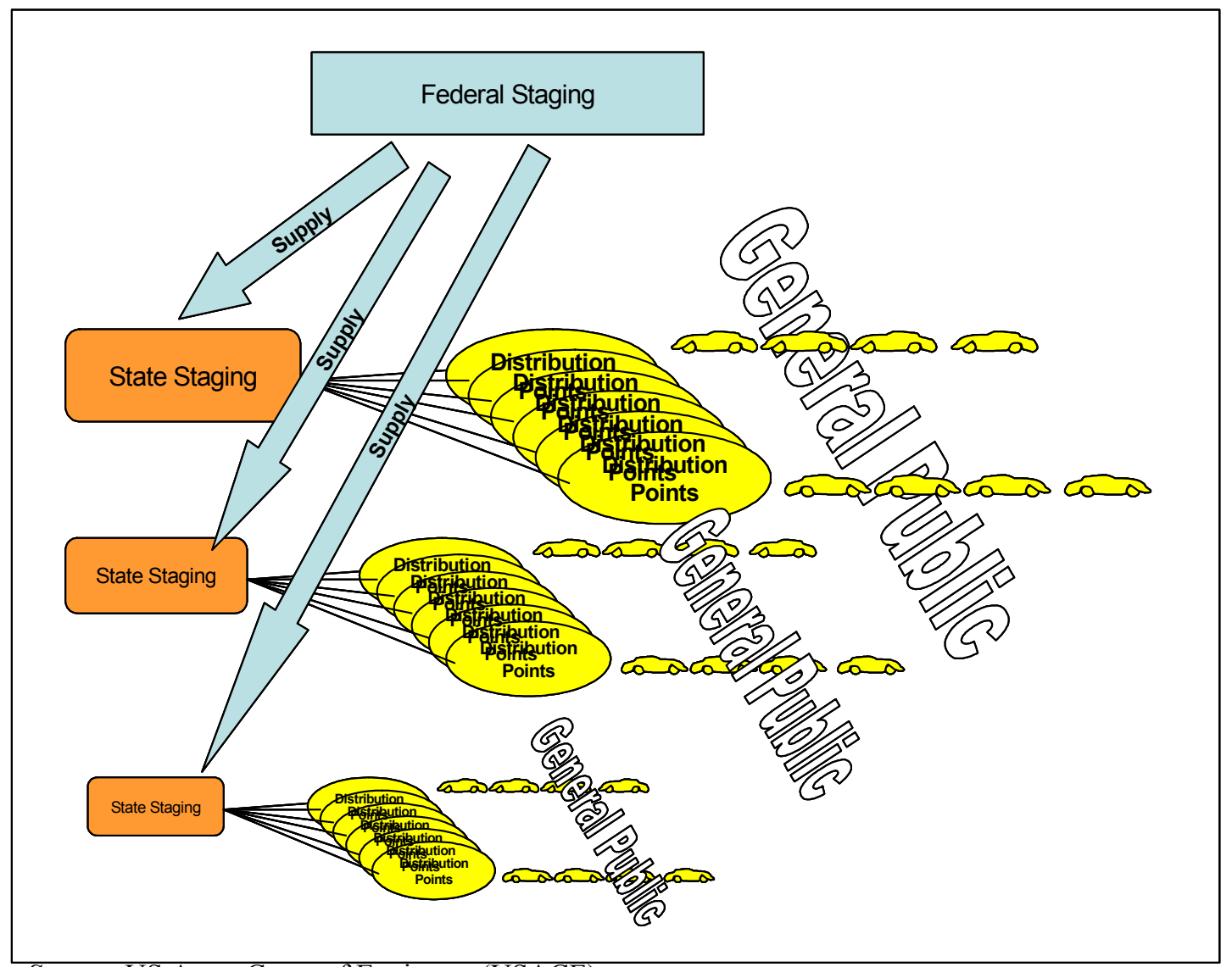

Source: US Army Corps of Engineers (USACE),

http://www.englink.usace.army.mil/igp/commodities.htm

The designated assembly points described by NIMS refer to staging areas and points of distribution (PODs). Generally, a staging area "is a location near or in the disaster area where personnel and equipment are assembled to coordinate response before deployment to an operational site within the disaster area" (Orange County, CEMP, A-18). PODs are "locations where in-kind donations of food, water, and other supplies received from the resource staging centers will be given directly to residents. Distribution points may be located in parking lots or open fields in the disaster area, as close to victims as possible" (Orange County, CEMP A-13).

Like staging areas, PODs can be classified into three different categories Type I, Type II, and Type III - determined by population base. The following set of diagrams maps the design utilized by each POD type. 


\section{Figure 2: Point of Distribution (POD) Type $\mathbf{I}^{2}$}

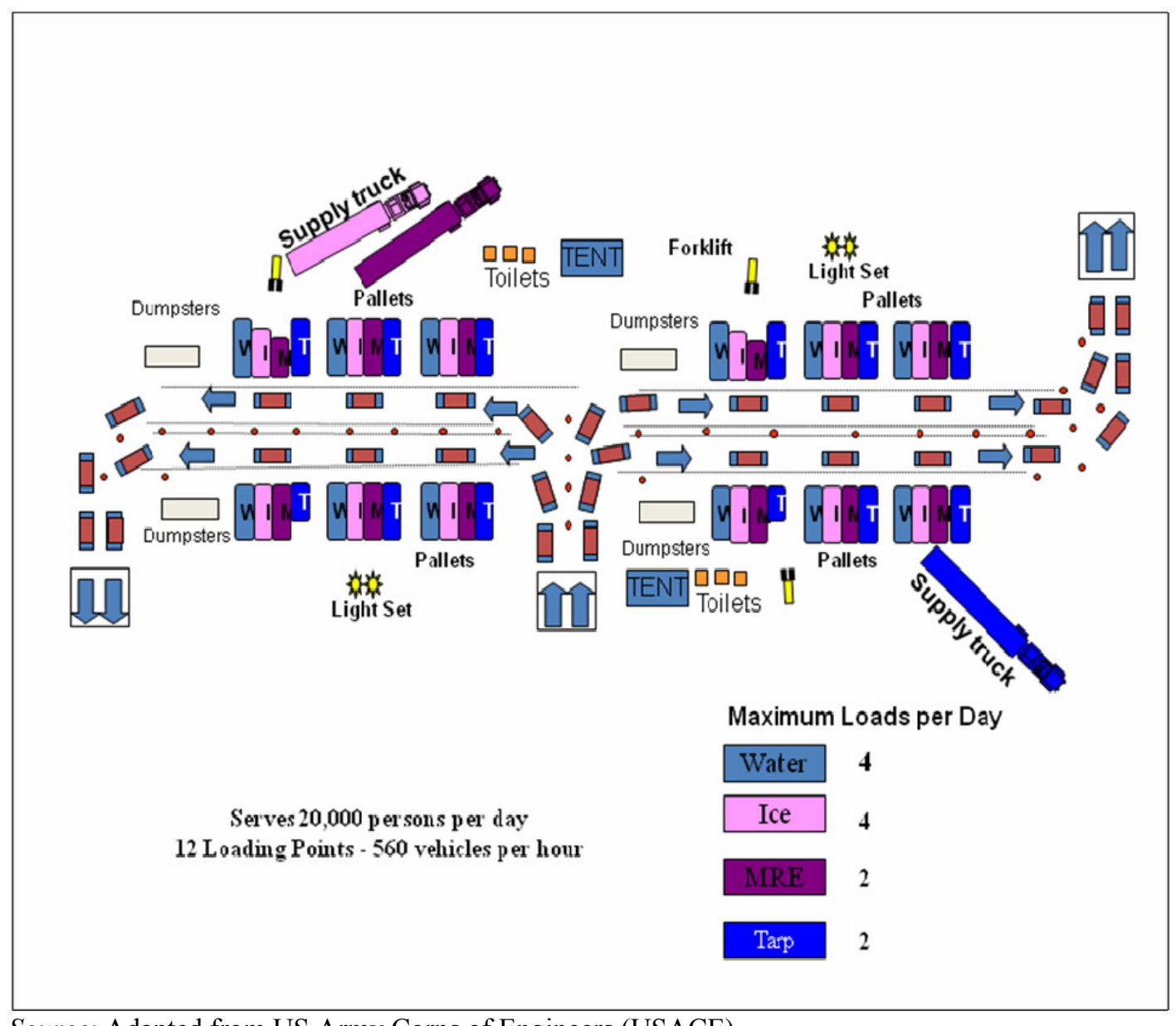

Source: Adapted from US Army Corps of Engineers (USACE),

http://www.englink.usace.army.mil/igp/commodities.htm

2 Note: Individual vehicles drive through and ice and water are loaded into their trunks. Recommend one case of water, 2 or 3 bags of ice per vehicle, and 6 MRE's. Supply trucks for ice, water, MRE's and tarps are to be off-loaded promptly and returned for re-supply. See appendix 1 for required resources for POD type I. 


\section{Figure 3: Point of Distribution (POD) Type II $^{3}$}

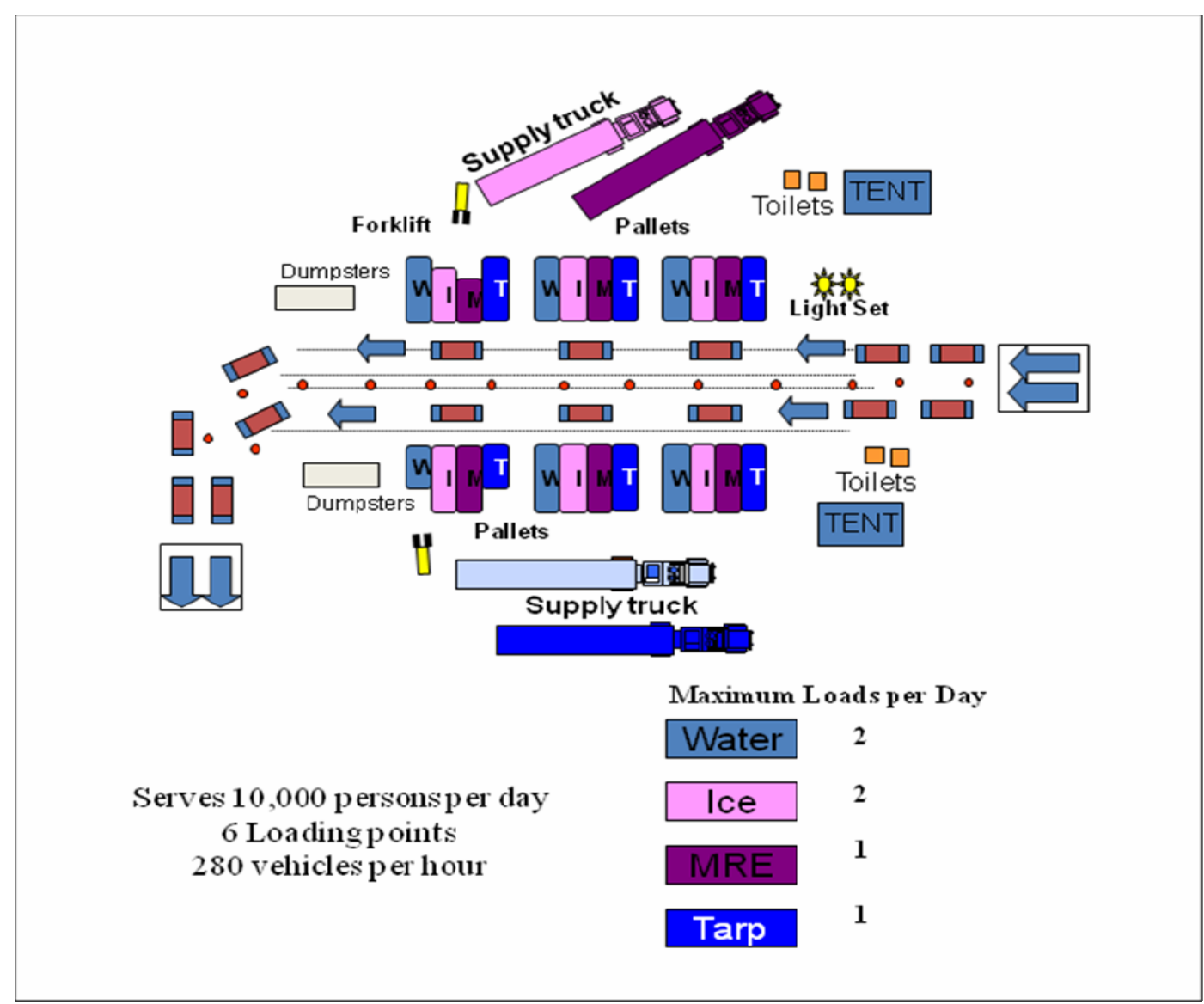

Source: Adapted from US Army Corps of Engineers (USACE), http://www.englink.usace.army.mil/igp/commodities.htm

The location of emergency resources is imperative to effective response and recovery. According to Hale and Moberg (2005), the private sector, similar to the public and nonprofit sectors, should be concerned with disaster preparedness and therefore should select "a minimum number of emergency resource locations that provide logistics managers with quick access to critical resources while minimizing the total costs spent by the supply chain" (201). The authors propose a set of four steps for site selection: (1) identify the emergency resources needed at each secure location; (2) identify all critical cities within the supply chain; (3)

3 Note: Individual vehicles drive through and ice and water are loaded into their trunks. Recommend one case of water, 2 or 3 bags of ice per vehicle, and 6 MRE's supply trucks for ice, water, MRE's and tarps are to be off-loaded promptly and returned for re-supply. See appendix 2 for required resources for POD type II. 
set maximum response time goals for access to emergency resources and minimum distances secure site storage areas; and, (4) identify the number and approximate location of emergency resource facilities.

\section{Figure 4: Point of Distribution (POD) Type III ${ }^{4}$}

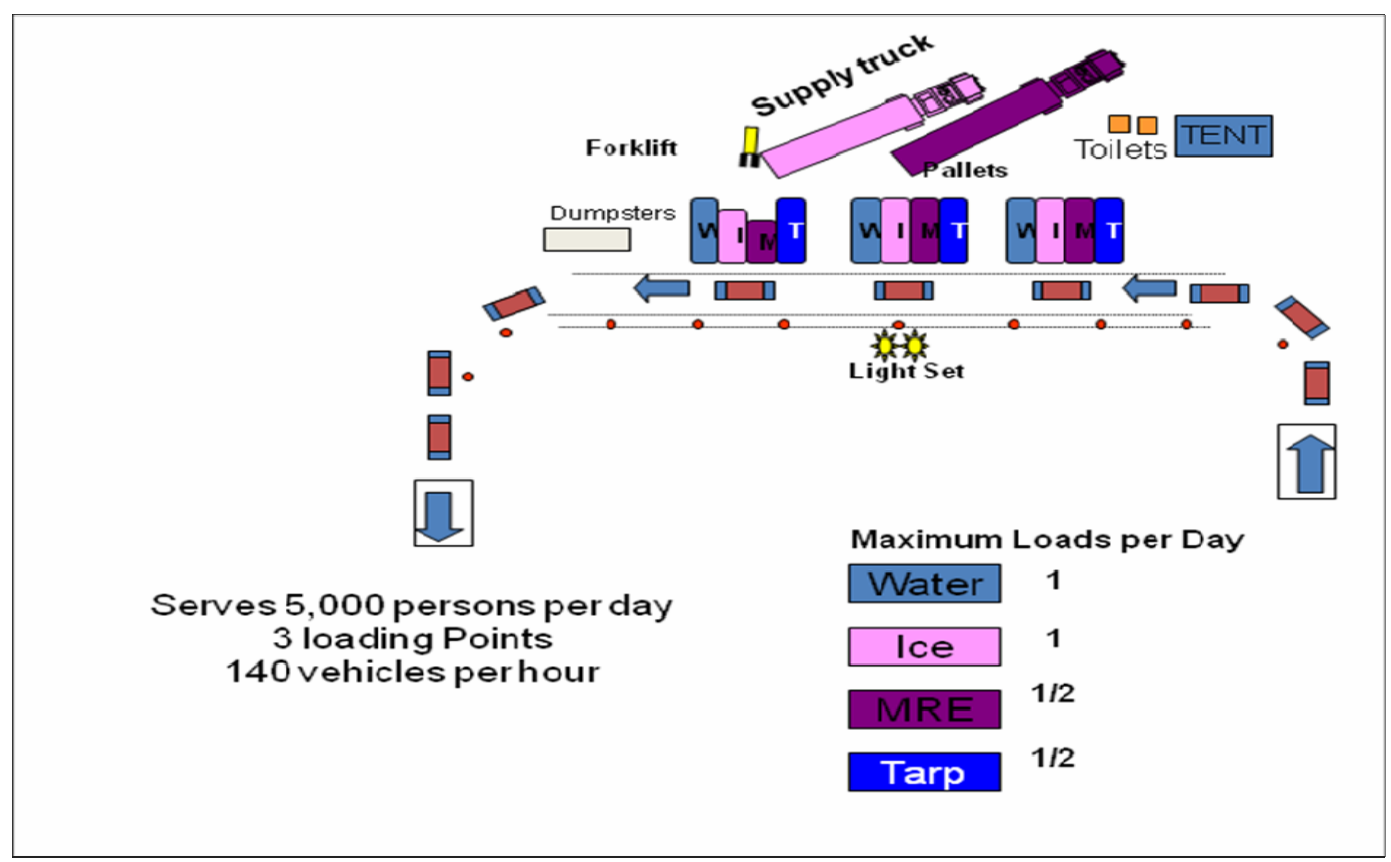

Source: Adapted from US Army Corps of Engineers (USACE),

http://www.englink.usace.army.mil/igp/commodities.htm

It is evident that field logistics sites, such as staging areas and POD's, demand strategic consideration and tactical pre-disaster decision-making. To ensure preparedness, these elements must become solid fixtures in emergency management planning. Each of the steps mentioned for site selection is integral to the overall preparedness design. In an effort to learn more about how government is actually preparing logistical operations this research involved a series of information collection methods discussed in the following section.

4 Note: Individual vehicles drive through and ice and water are loaded into their trunks. Recommend one case of water, 2 or 3 bags of ice per vehicle, and 6 MRE's supply trucks for ice, water, MRE's and tarps are to be off-loaded promptly and returned for re-supply. See appendix 3 for required resources for POD type III. 


\section{METHODS}

We gathered data from multiple sources concerning staging area selection and logistics planning. Staging area selection and decision-making includes local, state and federal agencies. We identified individuals from each level of government to interview. We focused on individuals that had significant experience with recent disasters. Several representatives from city and county emergency management agencies were interviewed in person. Those contacted and interviewed via telephone and email included FEMA representatives and staff of the FDEM Unified Logistics Section. In each case, discussions focused on the planning, selection, and interorganizational and intergovernmental coordination relevant to staging areas.

Representatives from past, present and potentially future staging area sites were also contacted via telephone interview and e-mail. Each site representative was asked to provide information on his or her individual site relevant to the criteria to be met for staging area candidacy. These discussions were further supplemented by the information provided by each location's website.

All other data utilized by this study was gathered from sources such as the websites of the Department of Homeland Security, FEMA, FDEM, Florida and select city and county governments, Florida Fairgrounds, United States Census Bureau, and Press Release Newswire. Reports, manuals, and official documents were gathered and reviewed from a variety of emergency management agencies.

\section{FINDINGS AND DISCUSSIONS}

Presently, there are no officially-documented guidelines governing the selection of staging areas among any level of government. Emergency management plans only list staging areas as an element of resource distribution planning. ${ }^{5}$ According to a recent Government Accountability Office (GAO 2007, 2006) report, FEMA does not have operational plans in place nor does it have detailed information on the capabilities and resources of each state and local government. FEMA accounts for "location, quantity, and types of supplies," yet it does not track those supplies in transit. Logistic centers and storage facilities operated by FEMA have not been found to be strategically located and FEMA does not provide the needed amount of logistic sites. Further, the supply distribution system utilized by FEMA is not believed to be functioning well due to a lack of transportation planning and distribution sites. Small core staff is another problem for FEMA's logistics (GAO 2007).

\footnotetext{
${ }^{5}$ They do not, however, specifically list criteria to be used for the selection of locations for staging.
} 
FDEM has chosen more comprehensive guidelines, outlining criteria to be used in the selection of CSAs and PODs. According to the FDEM's Logistical Technical Bulletin (2005), CSAs should have all of the following at minimum: (1) $50,000 \mathrm{sq} \mathrm{ft}$ of warehouse storage; (2) 1-2 loading docks; (3) 150,000 sq ft of hardstand; (4) 1 forklift and 2 pallet jacks; and, (5) 300' X 300' ft clear area designated as a helicopter landing zone. In addition, the site of the CSA should be conducive to one-way traffic and be located near major highways. PODs are selected based on population base and therefore are responsible for serving a specific type of community - densely populated (Type I) or outlying area/special community (Type I \& II). CSAs and PODs do not serve the same purpose and should never be collocated.

A number of other sources have been researched to establish a set of standards applicable to all staging area selection. These documents include the FDEM's Logistical Technical Bulletin (2005), FEMA All Hazards Emergency Operations Planning (1996), Staging Area Job Aid J236 (National Wildfire Coordinating Group, 2004), and The Central Florida Fairgrounds as a Forward Staging Area for Disaster Relief (2006). Based on the information these documents provide a list of general criteria has been set forth below.

Location: Sites should be located in a locally known location, on the inbound route between the resources and the incident where resources can be deployed immediately, yet removed from harm and at a safe distance from disaster refugees.

Operations Center Location: Sites should be located in relative proximity to emergency operation centers.

Access: Sites should be accessible from major highways and thoroughfares, by large vehicles including semi-trucks, by helicopter, and provide at least two entries/exits.

Helicopter Access: A minimum area of 300' x 300', clear of trees, wires or any other obstructions, is necessary for a helibase or heliport.

Safety and Security: Sites should be in close proximity to the incident yet out of harm's way and at a safe distance from refugees. The facilities on site should be surveyed for stability and secured.

Demobilization: Time is a main consideration in site selection. A staging area site should be available for use as a critical facility for an extended length of time to be measured by the emergency manager. 
Hardstand: A total of 150,000 total square feet of paved or unpaved hardstand, which if unpaved consists of hard packed dirt, stone or shell. Paved is preferred. If unpaved, the hardstand should be able to support weights up to 65,000 pounds.

Equipment: Loading docks, forklifts and pallet jacks should all be located on site.

Storage: Sites should have a minimum of $50,000 \mathrm{sq} \mathrm{ft}$ of warehouse storage. Specific storage requirements may also be necessary for resources such as medicine.

Utilities: Sites should have telephone lines (landlines) and water (potable).

The above are suggested standards to be utilized in the selection of staging areas and are to be included in emergency management plans as well as followed during site selection. The State of Florida, through the FDEM, has led an exemplary role in preparedness through the incorporation and implementation of such standards on both a state and county level. Florida county emergency management departments are expected to list up to three pre-identified staging areas in their CEMPs. In Orange County, for example, the primary designated staging areas are the Orlando Executive Airport and The Orlando Convention Center (Cook 2006) and the secondary staging area is the Central Florida Fairground.

Although, the majority of the county CEMPS do not list specific staging areas they do explain that the sites are to be selected annually and based on the type of disaster. The state and several counties maintain confidential lists of staging area locations for security reasons. The following are examples of CSAs that have been pre-identified by their respective county. Bay County fairgrounds; Collier County - fairgrounds, airport; Gilchrist County - farmer's market or agricultural shed; Hardee County - farmer's warehouse and parking lots, public park; Hernando County - fairgrounds and airport; Hillsborough County - Florida State Fairgrounds, Tampa International Airport and the Strawberry Festival Grounds in Plant City; Indian River County - fairgrounds airport; Miami-Dade County - site based on event and location of disaster; Orange County - public and private sector facilities that can be utilized during an emergency/disaster response. As can be seen from these examples, flea markets, agricultural centers, farmers markets, industrial parks, fairgrounds and small airports are all popular staging area locations at the county level. At the state and federal levels, public locations such a military bases are preferred. 


\section{CONCLUSIONS AND RECOMMENDATIONS}

The purpose of this study was to acquire information regarding emergency management, to determine the purpose staging areas serve, to define the types of staging areas utilized, to identify the criteria used in selection of and to distinguish staging areas from other field logistics sites. It has been found that emergency management theory is a constantly evolving topic of discussion among academics and practitioners wherein current discussion revolves around recent disasters, such as the heightened preparedness discussions post-Hurricane Katrina.

In the aftermath of Hurricane Katrina, FEMA's logistic area planning and disaster preparedness have been harshly criticized. The military took over much of the logistic mission from FEMA during Katrina response operations and Congress demanded FEMA to develop more flexible and responsive logistics for the future (GAO 2007). Both reactions emphasized the role of resource staging and distribution. The purpose of staging areas in relation to preparedness is contingent upon site selection and operational capabilities. Pre-selection of staging areas and their inclusion in emergency plans are crucial elements in planning that requires continual and focused consideration. No officially documented criterion exists throughout emergency management plans, yet a general set of criteria is often considered. Staging areas distinguishing nature from PODs, pre-positioning versus distribution of supplies, should be clarified in the emergency management plan.

Based on the research it is recommended that first, federal, state and local departments of emergency management develop communication channels that are open and interconnected in an effort to allow for ongoing and constructive discussion of logistics planning and operations. Second, that each level of government create and adopt official site-selection standards for all field logistical sites based on the criterion presented paying specific attention to staging areas. Third, the guidelines, standards and protocols established should be formally documented in every emergency management plan and should be reviewed on an annual basis making any necessary changes as presented. And fourth, each sector- public, private and nonprofit - should be engaged in field logistic site selection and operation. Their collaboration in the provision, staging and distribution of resources is critical in fully meeting the needs of the general public. These recommendations are most important at the state and local levels where disaster hits directly and response can be the most timely and effective. As previously discussed, disasters have a costly impact on the economy and members of the community. Implementation of these recommendations will fill the gaps and replace the inconsistencies presently weakening emergency management and, in effect, foster forward-thinking planning practices necessary for disaster preparedness. 


\section{APPENDICES:}

\begin{tabular}{|c|c|c|c|c|c|}
\hline \multicolumn{6}{|c|}{$\begin{array}{c}\text { Appendix 1: TypeI Distribution Point Resources Required } \\
\text { Type I Distribution Point }\end{array}$} \\
\hline \multicolumn{4}{|c|}{ Manpower } & \multicolumn{2}{|c|}{ Equipment } \\
\hline \multirow{9}{*}{ 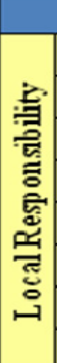 } & Type & Day & Night & Type & Number \\
\hline & Manager & 1 & 0 & Forklifts & 3 \\
\hline & Team Lea der & 2 & 1 & Pallet Jacks & 3 \\
\hline & Forklift Operator & 2 & 3 & Power Light Sets & 2 \\
\hline & Labor & 57 & 4 & Toilets: & 6 \\
\hline & Loading Point & & & Tents & 2 \\
\hline & Back-up Loading PT 18 & & & Dumpsters & 4 \\
\hline & Pallet Jacks Labor 3 & & & Traffic Cones & 30 \\
\hline & Totals & 70 & 9 & Two-way radios & 4 \\
\hline \multirow{3}{*}{ 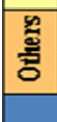 } & Law Enfor cement & 4 & 1 & & \\
\hline & Community Rel. & 4 & 0 & & \\
\hline & Grand Total & 78 & 10 & & \\
\hline
\end{tabular}

\begin{tabular}{|c|c|c|c|c|c|}
\hline \multicolumn{6}{|c|}{ Type II Distribution Point } \\
\hline \multicolumn{4}{|c|}{ Manp ower } & \multicolumn{2}{|c|}{ Equipment } \\
\hline \multicolumn{2}{|r|}{ Type } & Day & Night & Type & Number \\
\hline \multirow{7}{*}{ 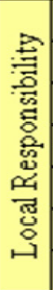 } & Team Lea der & 1 & 0 & Forklifts & 2 \\
\hline & Forklift Operator & 1 & 2 & Pallet Jacks & 2 \\
\hline & Labor & 28 & 3 & Power Light Sets & 1 \\
\hline & Loading PT & & & Toilets & 4 \\
\hline & Back-up Loading PT 9 & & & Tents & 2 \\
\hline & Pallet Jacks Labor & & & Dumpsters & 2 \\
\hline & Totals & 30 & 5 & Traffic Cones & 15 \\
\hline \multirow{3}{*}{ 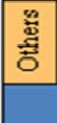 } & Law Enfor cement & 2 & 1 & Two-wayradios & 0 \\
\hline & Community Rel. & 2 & 0 & & \\
\hline & Grand Total & 34 & 6 & & \\
\hline
\end{tabular}

Source: US Army C orps of Engineers (USACE), http://wnw englink.usace army.miliga/com modities.htm 


\section{Appendix 3: Type III Distribution Point Resources Required}

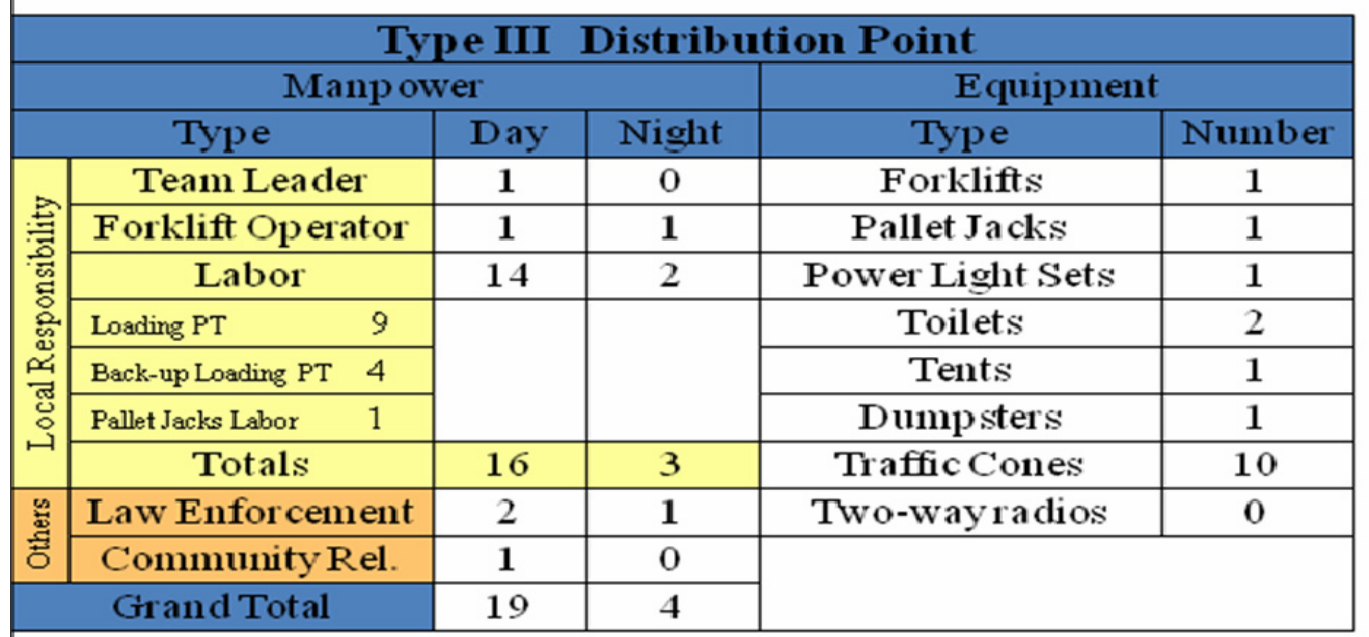

Source: US Army Corps of Engineers (USACE), ttp:/www englink usace arm y m il/igp/com m odities.htm 


\section{REFERENCES}

Alexander, David. (2005) Towards the Development of a Standard in Emergency Planning. Disaster Prevention and Management 14 (2): 158-175.

Auf der Heide, Erik. (1989). Disaster Response: Principles and Preparation and Coordination, St. Louis, MO: The C.V. Mosby Company.

Bousquet, S. B. Adair, and C. Squires. (2004). "Unlike Andrew, Aid's Right on Charley's Heels," St. Petersburg Times, 17 August, p. A1.

Center for Community Partnerships, College of Health \& Public Affairs, University of Central Florida. (2006). The Central Florida Fairgrounds as a Forward Staging Area for Disaster Relief. Final report.

Chertoff, Michael. (2005). Overhauling Relief Logistics. Traffic World October 24: 6.

Comfort, Louise K. (2002). Rethinking Security: Organizational Fragility in Extreme Events. Public Administration Review 62: 98-107.

Comfort, Louise K. and Thomas W. Haase. (2006). Communication, Coherence, and Collective Action: The Impact of Hurricane Katrina on Communications Infrastructure. Public Works Management \& Policy 10 (3): 328-343.

Cook, Preston. (2006). Orange County Emergency Management Office, Executive Director. Personal communication. (01/30/2006).

Department of Homeland Security (DHS). (2004). National Response Plan $(N R P)$. Washington D.C.: Department of Homeland Security.

Department of Homeland Security (DHS), FEMA. (2003). National Urban Search and Rescue (US\&R) Response System: Field Operations Guide, available at

http://www.fema.gov/pdf/usr/usr fog sept 252003 color final.pdf [accessed September 10, 2006].

------. (2005). Office of State and Local Government Coordination and Preparedness. ODP's Prepositioned Equipment Program.

Drabek, Thomas. E. (2003). Strategies for Coordinating Disaster Responses. Boulder, CO: University of Colorado, Natural Research and Applications Information Center.

Dynes, Russell R. and Kathleen J. Tierney (eds.). (1994). Disasters, Collective Behavior, and Social Organization. Newark, Delaware: University of Delaware Press.

Federal Emergency Management Agency (FEMA). (2004). FEMA National Incident management System Preparedness, available at http://www.fema.gov/txt/nims/nims doc3-5.txt [accessed October 12, 2006].

-------. (1998) FEMA US\&R Response System Logistics Specialist Training Manual. 
-------. (1996) FEMA Guide to All Hazards Emergency Operations Planning, available at http://www.fema.gov/pdf/rrr/slg101.pdf [accessed October 12, 2006].

Florida Department of Transportation. (2004). Access from the Strategic Intermodal System to Emergency Evacuation Routes. Tallahassee, FL: Florida Department of Transportation.

Florida Division of Emergency Management (FDEM). (2006). County Logistic Planning Standard Operating Guidelines. Draft report.

Gooley, Toby B. (1999). In Times of Crisis, Logistics is on the Job. Logistics Management \& Distribution Report 38.9 (Sept 30, 1999): 82.

Government Accountability Office (GAO). 2007. Homeland Security: Preparing for and Responding to Disasters, available at http://www.gao.gov/new.items/d07395t.pdf [accessed April 18, 2007].

------. (2006). Catastrophic Disasters: Enhanced Leadership, Capabilities, and. Accountability Controls Will Improve the Effectiveness of the Nation's Preparedness, Response, and Recovery System, available at http://www.gao.gov/new.items/d06618.pdf [accessed April 10, 2007].

Hagan, Chuck, Chief State Unified Logistics, State of Florida Division of Emergency Management. (2006). Personal communication. (01/12/2006 03/15/2006).

Hale, Trevor and Christopher R. Moberg. (2005). Improving Supply Chain Disaster Preparedness: A Decision Process for Secure Site Location. International Journal of Physical Distribution \& Logistics Management 35 (3): 195-207.

Kapucu, Naim and Montgomery Van Wart. (2006). The Emerging Role of the Public Sector in Managing Extreme Events: Lessons Learned. Administration \& Society 38 (3): 279-308.

Keane, Angela G. (2005). Looking for Logistics Lessons. Traffic World October 31: 15 .

Levans, Michael A. (2004). Disaster Response: Shippers Learn Tough Lessons from Hurricane Katrina. Logistics Management October: 18-20.

Lindell, Michael K., Carla Prater, and Ronald W. Perry. (2007). Introduction to Emergency Management. Hoboken, NJ: Wiley.

McEntire, David. A. (2002). Coordinating Multi-organizational Responses to Disaster: Lessons from the March 28, 2000, Forth Worth Tornado, Disaster Prevention and Management 11(5): 369-379.

-------. (2004). The Status of Emergency Management Theory: Issues, Barriers, and Recommendations for Improved Scholarship. Paper Presented at the FEMA Higher Education Conference June 8, 2004, Emmitsburg, MD 
McEntire, David A. and Amy Myers. (2004). Preparing Communities for Disasters: Issues and Processes for Government Readiness. Disaster Prevention and Management 13 (2): 140-152.

Mittler, Elliott. (1997). Management since Hurricane Andrew. Natural Hazards Research and Applications Information Center, Institute of Behavioral Science, University of Colorado. Working paper.

National Wildlife Coordination Group (NWCG). (2004). Staging Area Manager $J-236, N W C G$. Boise, ID: National Interagency Fire Center, National Fire Training Group, available at http://raining.fema.gov/EMIWeb/IS/ICSResource/assets/J-236.pdf [accessed October 12, 2006].

Perry, Ronald W. and Michael K. Lindell. (2007). Emergency Planning. Hoboken, NJ: Wiley.

Soto, Manuel D., Emergency Manager, City of Orlando, Orlando Operations Center. (2006). Personal communication. (01/30/2006).

State Emergency Response Team (SERT). (2005a). Logistics Technical Bulletin. Volume 1(1), April.

-------. (2005b). Florida's Unified Operational Response Plan to Hurricane Katrina (Task Force Florida).

------. (2005c). SERT Logistics Section: Organizational Structure and Resource Process, Field Support Briefing.

Sule, Dipeep. (2001). Logistics of Facility Location and Allocation. New York: Marcel Dekker.

Townsend, Frances F. (2006). The Federal Response to Hurricane Katrina: Lessons Learned. Washington DC: Office of the Assistant to the President for Homeland Security and Counterterrorism, available at www.whitehouse.com [accessed October 12, 2006].

US Army Corps of Engineers, (USACE, n.d.). Intergovernmental Plans: Commodities Planning and Distribution, available at http://www.englink.usace.army.mil/igp/commodities.htm [accessed October 5, 2006].

Wassenhove, Van. (2006). Humanitarian Aid Logistics: Supply Chain Management in High Gear. Journal of the Operational Research Society Volume 57 (5): 475-489.

Waugh, William L. Jr. (ed.). (2006). Shelter from the Storm: Repairing the National Emergency Management System after Hurricane Katrina. Special issue of The Annals of the American Academy of Political and Social Science Volume 604, March.

(2000). Living with Hazards, Dealing with Disasters: An Introduction to Emergency Management. Armonk, N.Y.: M.E. Sharpe. 